\title{
INCREASING THE QUALITY OF TEACHER'S PEDAGOGIC COMPETENCE TO DEVELOP STUDENT LEARNING MOTIVATION
}

\author{
Oleh \\ I Nengah Karsana ${ }^{1}$, Ni Made Suyeni ${ }^{2}$, Heny Perbowosari ${ }^{3}$ \\ ${ }^{123}$ Universitas Hindu Negeri I Gusti Bagus Sugriwa Denpasar, Bali, Indonesia \\ 1engahkarsane@gmail.com, ${ }^{3}$ henysari74@gmail.com
}

diterima 12 Oktober 2019, direvisi 11 Januari 2020, diterbitkan 29 Pebruari 2020

\begin{abstract}
Abstrak
Penelitian ini bertujuan untuk kompetensi pedagogik guru dalam perencanaan pembelajaran, proses pembelajaran, dan dalam meningkatkan motivasi belajar siswa. Untuk mencapai tujuan tersebut, penelitian ini menggunakan pendekatan kualitatif. Teknik pengumpulan data dilakukan melalui wawancara, observasi, dan studi dokumentasi. Prosedur analisis data adalah reduksi data, display data, dan verifikasi. Sedangkan subjek penelitian adalah kepala sekolah, wakil kepala sekolah, dan guru. Hasil penelitian menunjukkan bahwa: (1) Kompetensi pedagogik guru dalam perencanaan pembelajaran dilakukan dengan membuat draft RPP, namun sebagian guru tidak membawa RPP pada saat proses belajar mengajar berlangsung sehingga tujuan pembelajaran tidak tercapai secara maksimal; (2) Kompetensi pedagogik guru dalam proses pembelajaran dilakukan dengan mendalami dan memantapkan sejumlah materi pembelajaran sebagaimana terdapat dalam buku paket, adapun dalam proses pembelajaran terdapat pengelolaan kelas yang kurang baik dan pemanfaatan waktu yang kurang disiplin; dan (3) Kompetensi pedagogik guru dalam meningkatkan motivasi belajar siswa dilakukan dengan memberi kesempatan kepada peserta didik untuk terlibat aktif dalam menggunakan fasilitas teknologi informasi dan komunikasi dalam pencapaian tujuan pembelajaran, berkomunikasi secara efektif dengan peserta didik, dan melakukan tindakan reflektif untuk peningkatan kualitas pembelajaran.
\end{abstract}

Kata Kunci : Kompetensi Pedagogik; Motivasi Belajar.

\begin{abstract}
This study aims for teacher pedagogical competence in planning the learning, learning processes, and increasing student motivation. To achieve this goal, this study used a qualitative approach. Data collection techniques were done through interviews, observation, and documentation study. Data analysis procedures were data reduction, data display, and verification. While the research subjects were the principal, vice-principal, and teacher. The results showed that: (1) Teacher's pedagogical competence in planning the learning was done by making a draft lesson plan, but some teachers do not carry lesson
\end{abstract}


plans during the teaching and learning process so that learning objectives are not achieved optimally; (2) Teacher's pedagogical competence in the learning process was carried out by exploring and strengthening several learning materials as contained in the textbook, while in the learning process there is poor classroom management and less disciplined use of time; and (3) Teacher pedagogical competence in increasing student learning motivation was done by giving opportunities to students to be actively involved in using information and communication technology facilities in achieving learning objectives, communicating effectively with students, and taking reflective actions to improve the quality of learning.

\section{Keywords: Pedagogic Competence; Learning Motivation.}

\section{INTRODUCTION}

Nowadays there are many challenges faced by the education world, the final results of students could not make Indonesian proud, the quality of teaching and learning is questionable and students' learning motivation is still very low.

This must be corrected for better results in the teaching and learning process. The learning process is an active learning activity in arranging experiences, using real problems found in the environment. Learning is not passive, learning is an active process in gaining new knowledge and information experiences. After learning someone has skills, abilities, attitudes, and values.

Here, Sagala states that learning is understood as trying or practicing to get something clever. In its implementation learning is an individual activity to gain knowledge of behavior and skills by processing learning materials (Sagala, 2007).

Based on the statement above, it means that learning activities require practice and create experience so someone can acknowledge his special skill. To compile a perfect learning experience, the teaching and learning process should involve the function and use of learning methods, instructional media, evaluation techniques, regional characteristics, student characteristics, parental concerns, student motivation, and opportunities for teaching teachers, and so forth. The learning process that involves students directly in teaching and learning activities can create collaboration with other students and can get a lot of information. Hamalik states that learning is a combination that is composed including human elements, materials, facilities, equipment, and procedures that influence each other to achieve learning objectives (Omar Hamalik, 2012).

Based on the above statement, the ability to understand students an in-depth and implementing learning includes an understanding of the psychology of child development, children's health, social environment and the ability of students' parents is a cycle of understanding that must be understood by teachers in improving their pedagogical competence in the teaching and learning process.

In terms of the learning process, pedagogical competence is the ability of teachers to manage student learning. Every teacher must realize it to educate the nation's life. In the national education standard, the explanation of article 28 paragraph (3) point (a) states that pedagogical competence is the ability to manage learners' including an understanding of students, designing and implementing learning, testing learning outcomes, and developing participants students to actualize the various potentials they have. This condition, in Mulyasa's review, includes at least the following aspects, namely: (a) understanding of insight and educational foundation, (b) understanding of students, 
curriculum/syllabus development, (d) learning design, (e) implementation of learning that is educative and dialogical, (f) utilization of learning technology, ( $\mathrm{g}$ ) evaluation of learning outcomes (EHB), and (h) development of students to actualize their various potentials (Mulyasa, 2009). Teachers' tasks and responsibilities in professional development, a professional teacher is someone who has the ability and expertise in teacher training or he is a well educated and trained. Educated and trained means they are mastering various strategies or techniques in teaching and learning activities and mastering educational foundations as stated in teacher competencies. In the present situation, the tasks and responsibilities of teachers in professional development do not seem to have done much. The most prominent are the duties and responsibilities as a teacher and class administrator. Sudjana states that basically, the competency of the teacher is to act as a teacher, supervisor, and as a class administrator. To analyze the teacher's task as a teacher, the teacher's ability or competence which has a lot to do with efforts to improve the process and learning outcomes can be grouped into four abilities namely: (a) planning teaching programs, (b) implementing and leading/managing the teaching and learning process, (c) assessing the progress of the teaching and learning process, and (d) mastering the subject to master the field of study or the subjects being taught. These four abilities are abilities professional level teachers must fully master that (Sudjana, 2011).

Based on the description above, the concept of teacher competency can be interpreted as the basic ability to carry out teacher tasks that can be seen from the ability to plan learning, the ability to conduct or manage the teaching and learning process, and the ability to assess the teaching and learning process.

\section{METHOD}

This research used quantitative research. Qualitative research is research that intends to understand the phenomena about what is experienced by research subjects, for example; behavior, motivation, perception, other actions, holistically and descriptively in the form of words and language in a particular context naturally and by using various scientific methods. The method of determining the informants in this study was purposive sampling technique on the determination of samples based on specific objectives to be achieved.

Data collection methods used in this study were methods such as (1) observation, (2) interview, (3) documentation. After the data were collected, the data were processed with descriptive data with the steps: 1) argumentative inductive techniques through the process of description - categorization specifications (details-classification) then depart from specific facts inductively to the conclusion, (2) Classification and (3) Interpretation. Description of the data was done through interviews, observations and documents in the writing. Classification was done to interpret the data that has been described and classified.

\section{RESULTS AND DISCUSSION}

It would seek the results to interpret the findings of research in the field. It bases on a perception that the main purpose of qualitative research is to obtain a meaning of the reality that occurs. A systematic discussion of the results will be presented as follows.

\section{Teacher Pedagogical Competencies in Planning the Learning}

The results of the study proved that the teacher's pedagogical competence in planning learning is based on curriculum and syllabus. In the learning plan, it includes an analysis of learning material which includes competency standards, basic competencies, indicators, and subject. Regarding the learning plan, it is believed that the learning taught by the teacher will be more directed, continuous, and more flexible. 


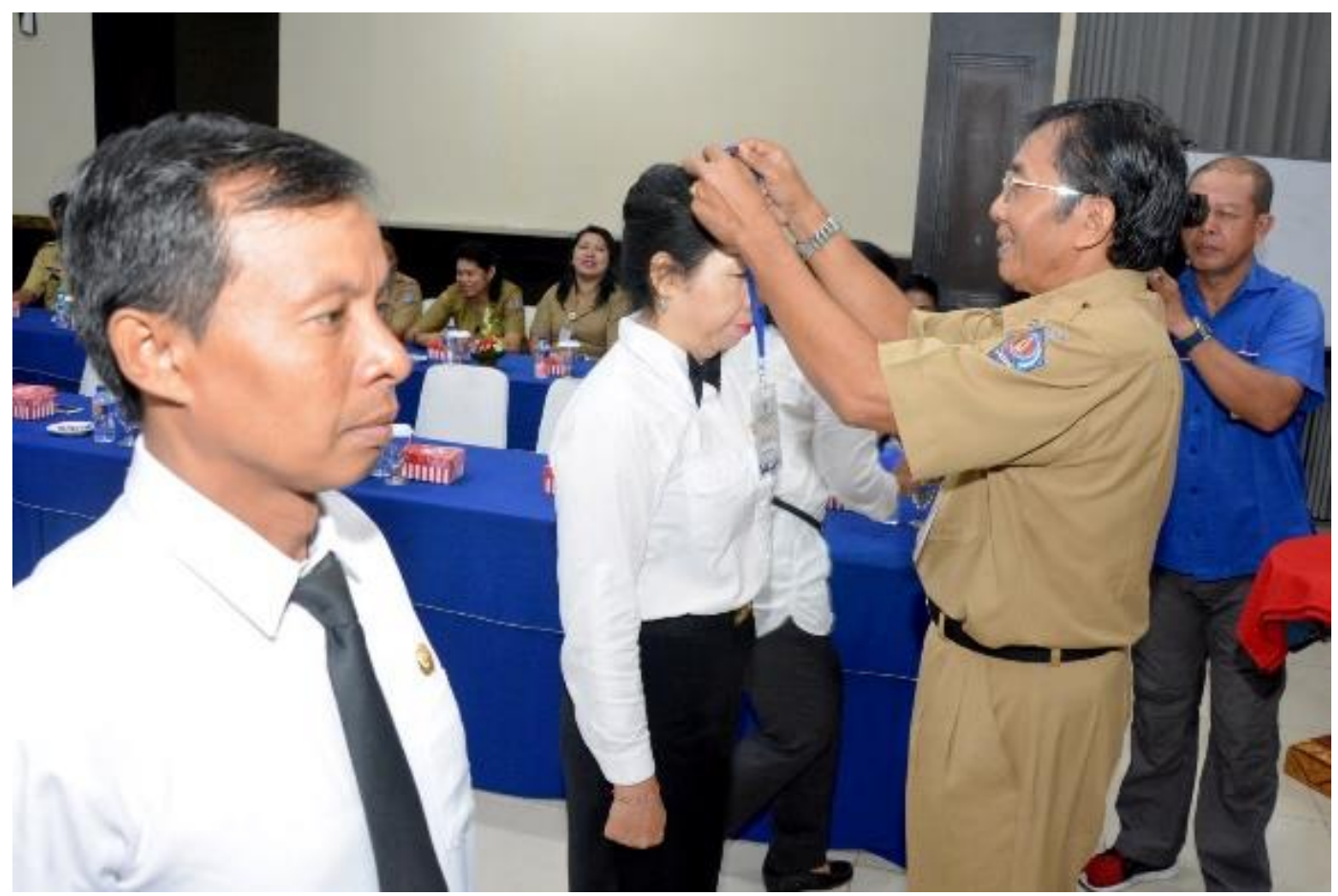

Figure 1. Government Holds Training of Prospective Principals For Elementary Teachers in Denpasar (Source : http://metrobali.com/pemkot-gelar-diklat-calonkepala-sekolah-bagi-guru-sd-di-denpasar)

This is consistent with the statement of Harun which says that teaching planning will be successful if it covers seven categories, namely: (a) planning based on clear objectives, (b) there is a unity of a plan, (c) logical, (d) continuity, (e) simple and clear, (f) flexible, and (g) stability. As the authors stated earlier planning is one of the initial functions of the activity management, in determining and using resources in an integrated manner which is expected to support the activities and efforts carried out efficiently and in achieving the objectives (Harun, 2010). Learning plan is the responsibility of the teacher in the teaching and learning process so the teacher must compete in several ways related materials including an annual program, semester program, syllabus, lesson plans, minimum completeness criteria, student attendance list, and grade book. For teachers, the most important planning is unit planning, weekly planning, and daily planning. Therefore, planning the learning at the education unit level is the first step of preparation that must be conducted. In its implementation, the first step is a review of the curriculum developed in the form of a syllabus. Furthermore, it is developed into an active, creative, innovative and enjoyable teaching and learning process. Good planning will also have a good impact on the teaching and learning process. A learning plan is a preparation that must be carried out by the teacher and is the first step of a learning activity.

\section{Teacher Pedagogical Competencies in Learning Process}

Other research results prove that we can observe the pedagogical competence of teachers in the learning process through several aspects, namely: mastering learning theory and learning principles that educate. The results proved that the teacher's pedagogical competence in the learning process was reviewed from the aspect of mastery of learning theory and the principles of learning by deepening each of the learning material conceptually through reading books and literature about each discipline, respectively. Develop a curriculum related to the subjects being 
taught. Further, it proved that the pedagogical competence of teachers in the learning process was reviewed from aspects of curriculum development related to the subjects being carried out by strengthening several learning materials to students properly and correctly and according to allocation learning time provided.

a) Facilitating the development of potential learners to actualize the various potentials they have. The results of the study prove that the teacher's pedagogical competence in the learning process to develop the potential of learners to actualize the various potentials possessed by providing several exercises in the form of homework related to learning material that has been taught.

b) Using the results of assessments and evaluations for the benefit of learning development of teaching materials. The success of education can be seen from the quality of teaching and learning process in the classroom which will directly show the mastery of learning management by the teacher so it also shows the learning achievements achieved by students. This is important, especially in teacher professionalism. SMA is a continuation of junior high school and is a package in basic education as a minimum education all Indonesian citizens must take that.

We can define the teaching and learning process in high school as an activity that tries to help students to get, change and or develop the skills, attitudes, ideas, appreciation, and knowledge they have. High school students with special characteristics need special attention and handling to make the best use of time at school. Therefore, to expedite the learning process it is necessary to pay attention to the learning management, both those contained within the teacher, students and those outside themselves. The teaching and learning process is the core of the overall education process with the teacher as the main role holder and a process that contains a series of actions. Teachers based on reciprocal relationships that take place in educational situations to achieve certain goals. Interaction or reciprocal relationship between teachers and students is the main requirement for the learning process. Interactions and learning events have a broader meaning, not just the relationship between teachers and students, but in the form of educative interactions.

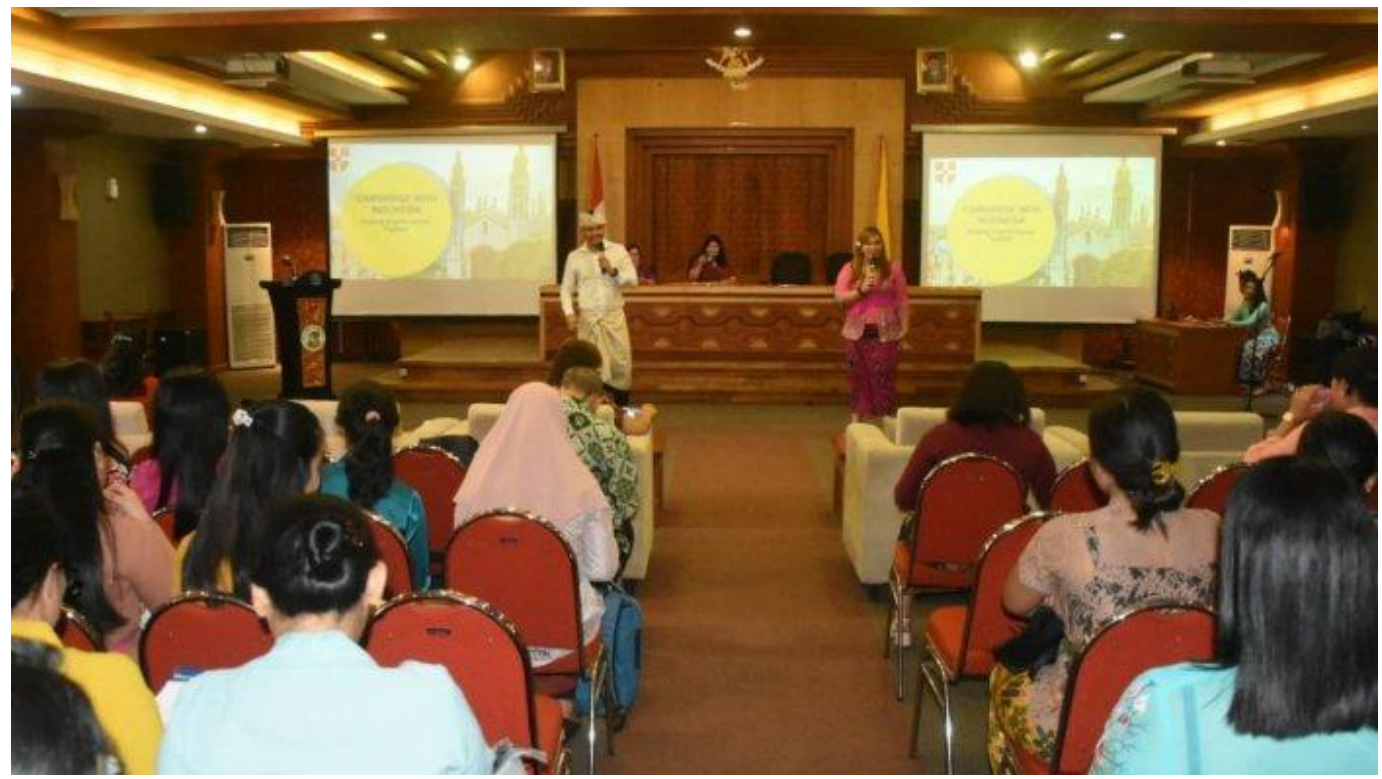

Figure 2. 300 Elementary and Middle School English Teachers in Denpasar Participate in Training (Source : https://bali.tribunnews.com/2019/08/22/300guru-bahasa-inggris-sd-dan-smp-di-denpasar-ikut-pelatihan-english-for-schools) 
This is in line with the opinion of Hamalik states that the lesson will be meaningful for students if the teacher tries to relate it to experiences, or experiences that have been previously owned (Hamalik, 2008). As according to Usman which states that the provision of explanations is one of the most important aspects of teacher activities in their interactions with students in the classroom, and teachers usually dominate the conversation and have a direct influence, for example in providing facts, ideas, or opinion (Usman, 2011). Therefore, its effectiveness must be improved to achieve optimal results from the explanation and discussion so that it is meant for students.

The description above explains that learning requires direct interaction between students and teachers. Teaching delivered by teachers should have a variety of methods that can arouse students' enthusiasm in teaching and learning in class.

\section{Teacher's Pedagogical Competencies in Improving Student Learning Motivation}

The results of the study proved that the teacher's pedagogical competence in increasing student motivation in high school can be done in various ways, namely:

a) Utilizing information and communication technology for learning interests. The results of the study showed that the teacher's pedagogical competence in increasing student motivation from the aspect of using information and communication technology for the benefit of learning to achieve learning objectives. Good organizational communication is expected to provide support for the achievement of organizational goals, regulate each role of people, groups, part of the organization, clarify the formal hierarchical structure of the organization, facilitate informal interactions, and others. Therefore, Engkoswara and Komariah, states that the effectiveness of organizational communication is determined by (a) a clear structure for each function and role of people/parts, (b) communication model, and (c) technological support capacity, namely the ability of the organization financially and human resources (Engkoswara; Komariah, 2011). The success of schools in achieving educational goals is also determined by how much the school can absorb the growth of technology to develop its capacity. The intended technology does not only support production or direct services but also relates to elements of communication within the organization technology must facilitate that. The technology in communication is intended as a tool, technique/way that can help teachers in carrying out their teaching assignments. In connection with the explanation above, Engkoswara and Komariah (2011), states that the technology in organizational communication categorize as follows: (a) technology in the form of written communication, it divides this type into printed documents and electronic documents. The preparation of printed documents in the organization includes planning, preparation, revisions, production, and distribution activities. As for electronic documents, the forms of preparation in organizations include Local Area Network (LAN), Wide Area Network (WAN), and the internet, and (b) technology in the form of oral communication. This can be done for individuals such as telephone, pager, voice mail, and groups including teleconference, presentation, software, and group decision support system. From this description, it can be understood that the use of information technology in 
learning needs is necessary for the development of teacher pedagogical competencies and improving the quality of students although many problems arise from the development of information technology. To respond to problems that arise from the development of information technology, it requires a teacher to understand the use and procedures for the workings of information technology. Communicate effectively, empathically, and politely with students.

The results showed that the teacher's pedagogical competence in increasing student motivation was done every working day by giving greetings and reprimands that are educational and improve student behavior. Communication is delivering a message between the sender and the receiver. Therefore, in a communication will occur if it has a communicator (people who deliver information), communicants (people who receive information), messages (something delivered in the form of information, news, feelings, instructions, wishes, desires, and so forth), media (the form or way the information is conveyed. The media can be oral, written, picture, video, music, and other forms), and effects (changes that occur in the communicant under communicators' expectations). This aspect is the most underlying for effective communication. Communication is a basic human activity. In a management review, it defines communication as one activity carried out to establish a relationship between managers and their subordinates. Therefore, communication needs to be done so that the intentions and messages conveyed can be received under the wishes of the sender of the news. Engkoswara and Komariah (2011), said that communication of transferring meaning/understanding from the sender to the recipient included three important parts of effective communication, namely the sender, receiver, and the success of sending meaning. The communication in the organization is understood as an effort to eliminate the gap so that the parties involved in the communication process become closer to one another. Thus, the nature of communication is mutual. Furthermore, it explains that communication is the transfer of information and understanding from one person to another. Communication will be more effective and quality if supported by an attitude of trust, acceptance, empathy, and honesty between the two.

From the above understanding, it shows that communication is an activity to make other people understand what it means in the communication process carried out. Besides, communication is a suggestion of transferring information from the communicator to the communicant or a system to form interwoven communication between individuals. 


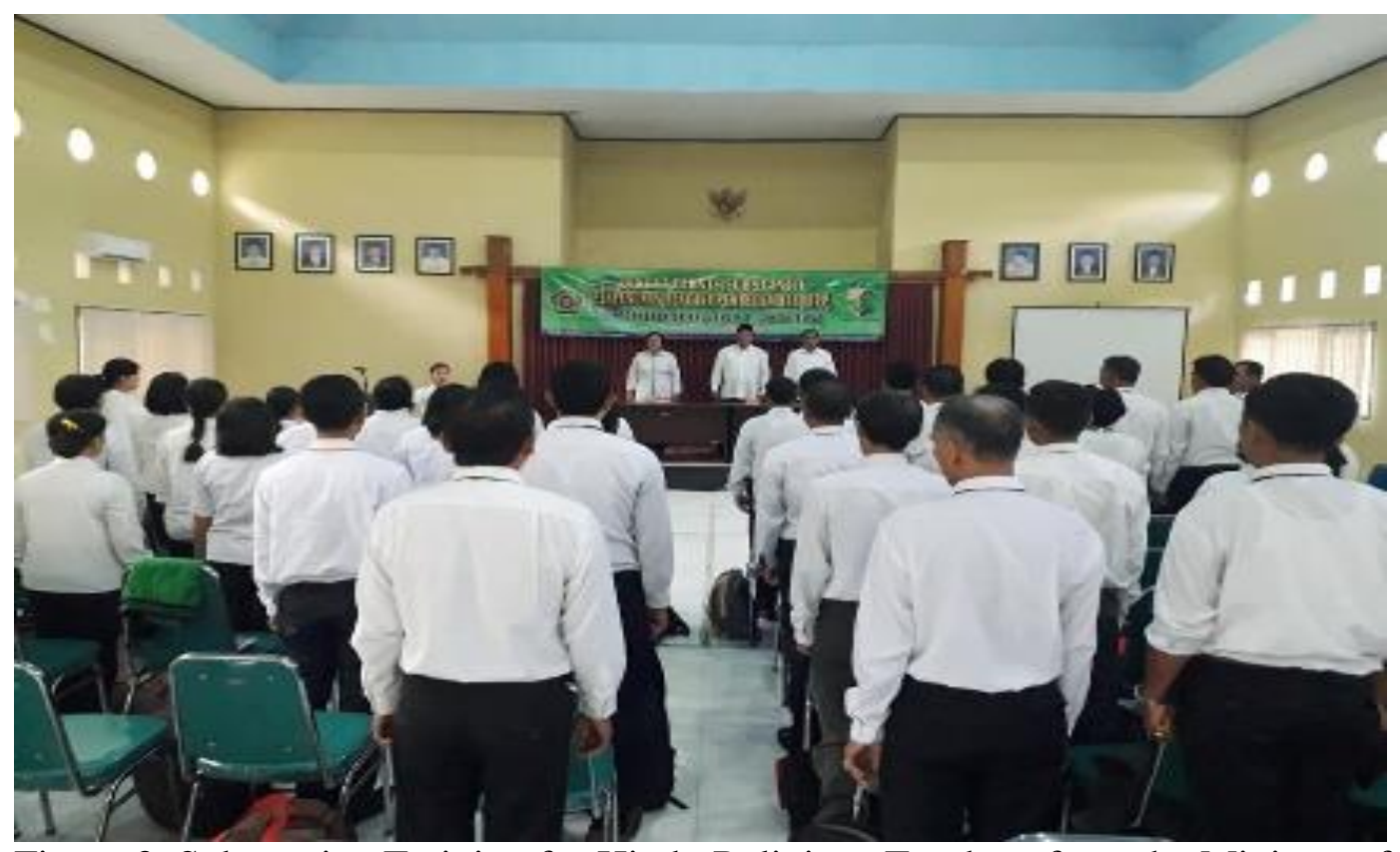

Figure 3. Substantive Training for Hindu Religious Teachers from the Ministry of Religion, West Lombok (Source : https://ntb.kemenag.go.id/baca/1552952220/ diklat-substantif-bagi-guru-agama-hindu-kemenag-lombok-barat-tahun-2019)

b) Perform reflective action for improving the quality of learning. The results proved that the pedagogical competence. The teacher used diagnostic tests for each taught subject to conduct reflective actions to improve the quality of learning. In Djamarah's review (2010: 320), what is meant by a diagnostic test is a test intended to find out the learning difficulties experienced by students based on the results of the previous formative tests. So it can be understood that the form of reflection in activities implemented by the teacher is to test the extent of learning difficulties experienced by students. Diagnostic tests require several questions for one area that is thought as a difficulty for students. The questions varied and focused on learning difficulties. As for learning difficulties in Djamarah's review (2008: 235), it is a condition in which students cannot learn naturally, due to threats, obstacles or disturbances in learning. There are no students who do not have problems in learning, apart from the intelligence factor, several indicators can cause students' learning difficulties with their respective perspectives.

\section{CONCLUSION}

From the research findings, there are several things to conclude :

1. The results proved that the teacher's pedagogical competence in planning learning was based on curriculum and syllabus. For the learning plan, it covers an analysis of learning material such as competency standards, basic competencies, indicators, and subject.

2. The pedagogical competence of teachers in the learning process in terms of (a) mastery of learning theories and principles of learning by deepening each learning material conceptually through reading books and respective disciplines literature, (b) curriculum development related to the subject was done by strengthening several learning materials to students according to the learning time allocation provided, (c) developing the potential of learners to actualize the various potential 
possessed by providing several exercises in the form of homework related to learning material, and (d) using the results of the assessment and evaluation for the benefit of learning was done by how identities student development through learning evaluation activities and determines several peer tutors for the development of teaching materials.

3. Teacher pedagogical competence in increasing student learning motivation can be done in various ways, there are: (a) allow students to use information and communication technology for the benefit of learning to achieve learning objectives, (b) communicate effectively, empathically, and politely every working day with students by giving greetings and reprimands to improve the behavior of students, and (c) take reflective actions to improve the quality of learning with tests diagnostic for each subject that has been taught.

\section{REFERENCE}

Engkoswara; Komariah, A. (2011). Administrasi Pendidikan. Bandung: Alfabeta.

Hamalik, O. (2008). Perencanaan Pengajaran Berdasarkan Pendekatan Sistem, Cet. VII. Jakarta: Bumi Aksara.

Hamalik, O. (2012). Pendekatan Baru Strategi Belajra Mengajar Berdasarkan CBSA. Bandung: Sinar Baru Algensindo.

Harun, C. Z. (2010). Manajemen Sumber Daya Pendidikan. Yogyakarta: Pena Persada.

Mulyasa, E. (2009). Praktik Penelitian Tindakan Kelas. Bandung: PT. Remaja Rosdakarya.

Sagala, S. (2007). Konsep dan Makna Pembelajaran. Bandung: Alfabeta.

Sudjana, N. (2011). Penilaian Hasil Proses Belajar Mengajar. Bandung: PT Remaja Rosydakarya.

Usman, H. (2011). Manajemen.Teori, Praktik, dan Riset Pendidikan. Jakarta: Bumi Aksara. 